Arch. histol. jap. Vol. 27 (November 1966)

P. $373-386$

Department of Anatomy (Prof. H. Kolkegami and Prof. T. Yamamoto)

Niigata University School of Medicine, Niigata, Japan

\title{
Synaptic Organization of the Lateral Pulvinar Nucleus in the Cat*
}

\author{
Yukio HiRATA（平田幸男）
}

Received August 1, 1966

The pulvinar nucleus belongs to one of the brain regions whose functions have not been elucidated fully until now. We have undertaken some experiments on this brain region and found that the pulvinar ablation induced peculiar responses of the lateral geniculate body to the visual deafferentation (HIRATA 1965), thus suggesting the farticifation of the pulvinar nucleus in visual perceptive activity of animals.

For the further exploration of the functions of this region, we have also carried out a series of experimental anatomical investigations on its relationships with the neocortex. While examining the cortico pulvinar projections using the technique of NAUTA and GYGAX (1954) we found it very difficult to ascertain the accurate sites of termination of the projection fibers. This situation impelled us to get understanding of the finer synaptic arrangement of this brain region.

\section{Materials and Methods}

Twenty lateral pulvinar nuclei from 10 adult cats were examined. Of these, certain cortical regions of 7 cats were ablated unilaterally either by subpial suction or by undercutting. Three kinds of cortical lesion were made: 1. middle and posterior suprasylvian gyri; 2. lateral gyrus, including the striate and peristriate cortices; and 3. both suprasylvian and lateral gyri. After survival of three to ten days, these animals were anesthetized with Nembutal and perfused from the left cardiac ventricle with buffered formalin solution(Hirata 1966). Portions of the bilateral lateral pulvinar regions were dissected out and cut into slices, postfixed in Millonig's fixative (1961), and embedded in Epon-epoxy resin (LuFT 1961). Thicker sections cut on Porter-Blum microtome were stained with buffered toluidine blue (YAмамото 1963) and counterstained after that with $1 \%$ aquous solution of safranin. The latter process stains the oligodendroglial nucleus and cytoplasm in dark rel, the pericapillary basement membrane and the collagen fibers if present in light red and the vascular endothelial and the pericyte nuclei and cytoplasm in pale red, thus making it easier to get orientation for trimming the field to be examined electron microscopically. Thin sections were stained after the method of MILLONIG (1961) and were examined on the Hitachi HS 7 electron microscope. In one case, about a hundred thicker sections (ca. $1.5 \mu$ ) were cut serially from Eponembedded material and stained with above stated toluidin safranin double stain. The observation of these serial sections enabled us to know considerably quantitatively the way of the three dimensional organization of the dendritic expansions of the pulvinar neurons, serving in this way as the substitute of Golgi-materials and helped us in analysing electron micro-

* This work is dedicated to the memory of the late Prof. Masaji SEKI. 
scopically observable synaptic arrangements of the region.

The brains of which portions of the pulvinar regions were taken for Epon-embedding, were then preserved in the formalin fixative. About a month later, frozen sections were made of these brains and treated by the technique of NAUTA and GYGAX (1954) for the demonstration of degenerated fibers from the cortical lesions.

\section{Observations}

\section{A. Gross orgnization of the lateral pulvinar nuclens (Fig. 1)}

This nucleus consists of a single type of neurons scattered seemingly randomly within the nuclear territory. The somata of the neurons with poor Nissl substances are $15-20 \mu$ in diameter and contain the ellipsoid nucleus of about $8-13 \mu$ diameter, with a few, deep indentations. Two to five dendritic trunks radiate from the somata, rather straightly in all direc-

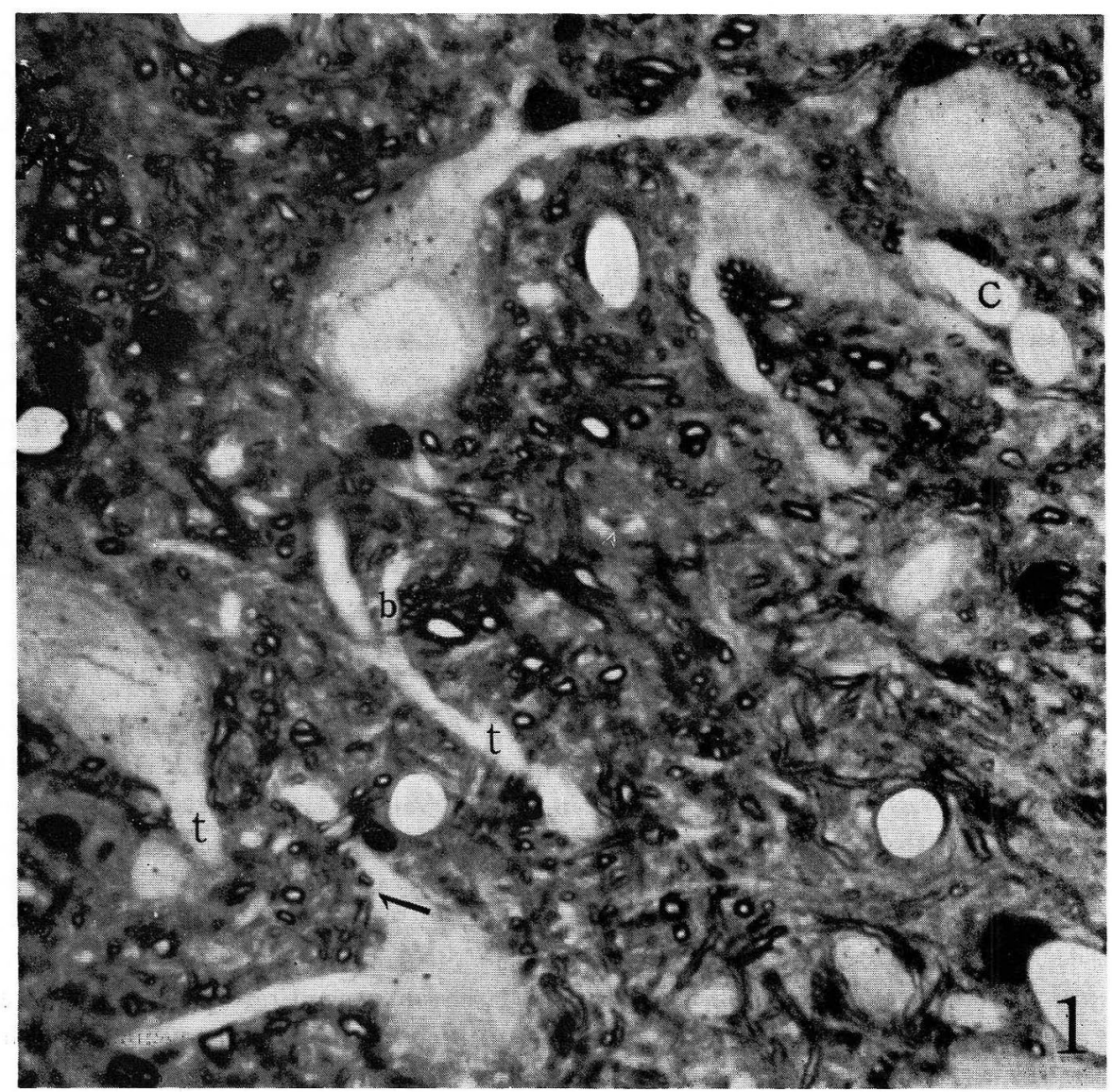

Fig. 1. Photomicrograph showing the general arrangement of a portion of the lateral pulvinar nucleus. $t$ Dendritic trunk radiating from the neuronal somata; $b$ dendritic branch from the trunk. One of the small processes issuing direstly from the trunk is indicated by an arrow. Epon section, toluidine-safranin stain. $\times 1,000$ 
tions. These dendritic trunks, $3-5 \mu$ in diameter at their initial segments, taper gradually toward the periphery to become as thin as $2-3 \mu$. Sometimes a few tiny processes or branches of $1 \mu$ or less in diameter are seen to issue directly from these dendritic trunks into adjoining neuropile (Fig. 1, arrow). The usual sites of division of the dendritic trunks into the thinner branches are at the distance of $40-50 \mu$ peripherally to the neuronal somata and most of the resulting branches of mainly about $2 \mu$ in diameter soon diverge further into finer secondary and tertiary branches. In addition to these thick and thin dendritic trunks and branches of the pulvinar neurons, there can be found light microscopically abundant, thinly myelinated"nerve fibers. Majority of these fibers do not exceed $4 \mu$ in diameter and run in scattered way or in bundles 20-30 fibers.

\section{B. Electron microscopy}

\section{Pulvinar neuron, or post-synaptic elements}

In addition to the light microscopical findings and the electron microscopical features common to the neurons of the central nervous system, only a few remarks are necessary to describe the morphological characteristics of the pulvinar neurons. Nissl substance of this neuron seems, not like that in the motor neurons where the lamellated type of rather straight, rough surfaced endoplasmic reticulum is predominant, to consist of irregularly branching endoplasmic reticulum and the ribosomes crowded on and among them. Neuronal somata and the thicker portion of the dendritic trunks are essentially devoid of synaptic contacts with any type of nerve terminal. At some patches of the surface of the distal, thinner half of the dendritic trunks, however, synaptic contacts are found to be made with apposed nerve terminals. Though considerably rare, thin processes containing filamentous structures, issuing directly from the dendritic trunk, corresponding perhaps to those found in the same situation in light microscopy, are seen making a specialized set of synaptic contacts with various types of nerve terminal (Fig. 3). This type of synaptic figure seems to coinside with the glomerular synapse of MAJOROSSY et al. (1965), and will be stated in detail in the following accounts.

The majority of synaptic inputs to the pulvinar neurons take place on the surface of the dendritic branches of less than $2 \mu$ in diameter (Fig. 4). More than half of the surface of a dendrite in cross section of diameter ranging $2-1 \mu$ is faced to the three to six nerve terminals of various types, some of these making synaptic contacts with the dendrite in concern. Sometimes, a spine-like short process is seen to bud from these regions of dendritic branches and to make a synaptic contact with a nerve terminal. In such a process, however, we could not observe any structure comparable to the spine apparatus (GRAY 1959). In the case of finer dendritic branches of the diameter less than $1 \mu$ (Fig. 5), only a smaller portion of its surface in cross figures is apposed to one or two nerve terminals which make synaptic junctions with it. By summarizing the observations above stated, we can divide, for convenience sake, the major area of synaptic junctions, or in other words, receptive areas of the pulvinar neurons into three portions: 1) the short, direct processes (diameter $0.5-1 \mu$ ) from the dendritic trunk, 2) the proximal dendritic branches $(1-2 \mu$ in diameter) and 3$)$ distal or peripheral dendritic branches (less than $1 \mu$ in diameter).

\section{Nerve terminals or presynapic elements}

Three types of them can be identified electron microscopically. a) The most numerous are 


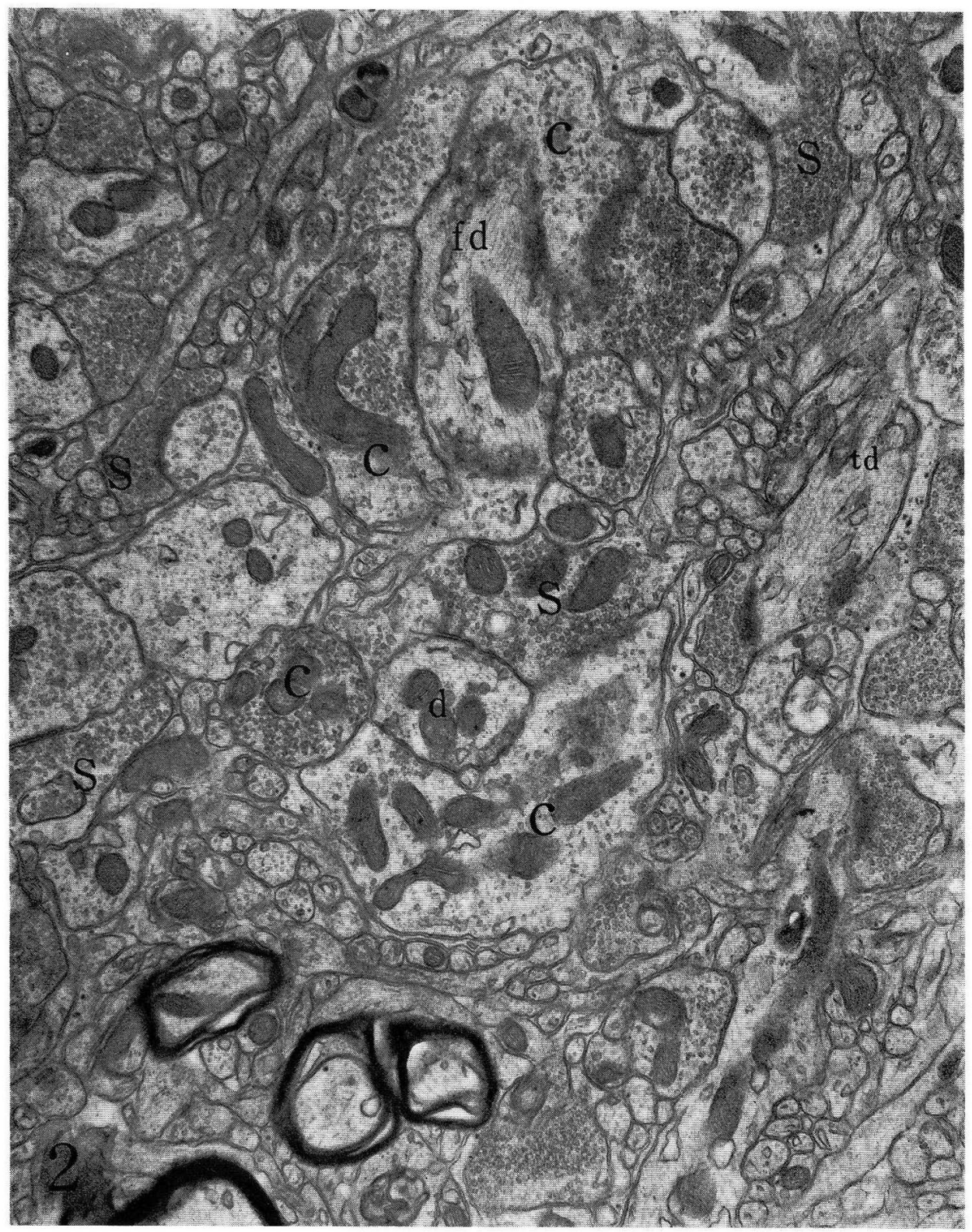

Fig. 2. Electron micrograph showing various constituents of the pulvinar neuropile and their gross arrangerent. $S$ s. v. t.; $C$ c. v. t.; $t d$ distal dendritic branch with dendritic tubules in it; $f d$ filamentous dendrite, seemingly the central dendrite of the glomerular synapse; $d$ proximal dendritic branch. $\times 15,000$

the terminals containing round or spherical synaptic vesicles of the diameter of $300-500 \AA$. This type of terminal appears in many cases as "bouton terminal" and is smaller in size (usually less than $1 \mu$ ) than the other two types of terminal. This terminal is abridged as 
s. v.t. in the following paragraphs and figures. b) The second are those terminals which include the cylindrical or flattened synaptic vesicles (Hirata 1966, BoDian 1966), measuring 250-300 $\AA$ in diameter and $400-$ $1000 \AA$ in length, in addition to the same sp'erical vesicles as seen in the s.v.t. This type will be noted as c.v.t. The c.v.t. is usually larger than the s.v.t. but smaller than the third type of terminal (see below). The c.v.t. appears in the form of either bouton terminal or of synapse "en passant"'(Fig. 6). The s.v.t. and c.v.t. are found over wide regions of the central nervous system other than the pulvinar region, and the general morphological features, the way of contacts with post-synaptic elements and the interrelationships between s.v.t. and c.v.t. previously described (Hirata 1966) are a'so the cases in the region now in problem. The synaptic junctions made by s.v.t. and c.v. t. seem to correspond, though not in strict senses, to the type I and II synapses of GRAY (1959) respectively. e) Rather infrequently occurs the third type of ending (Fig. 7). This is the largest of the three kinds of terminal (above $1.5 \mu$ usually and sometimes reaching $3 \mu$ in diameter.). This terminal is packed with numerous spherical synaptic vesịcles

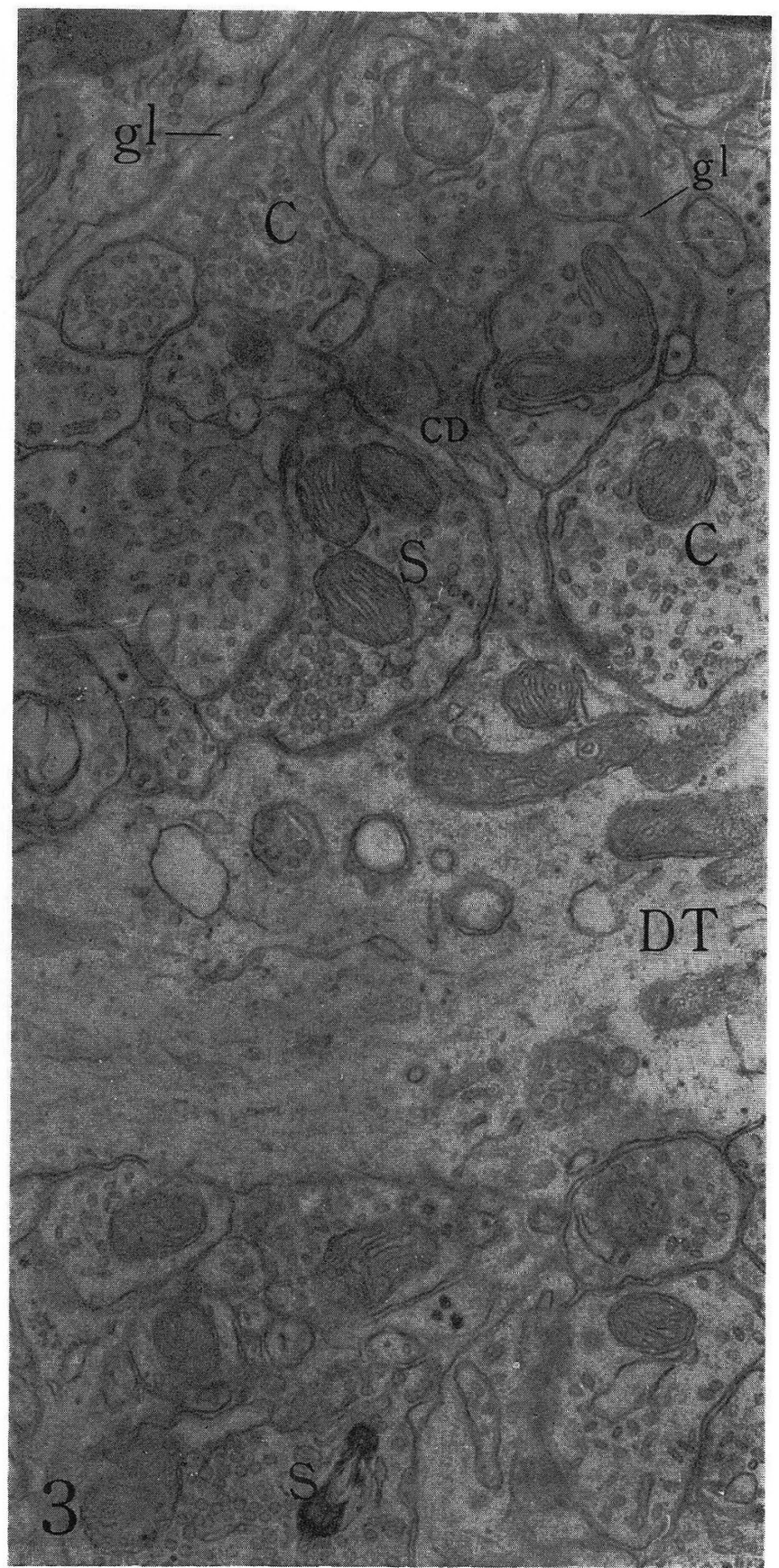

Fig. 3. In the upper half of the figure is shown the part of the ofo erular synapse, formed by several terminals of different types $(C$ c. v. t., $S$ s. v. t.) around the central dendrite $(C D)$ which issues directly from the dendritic trunk $(D T)$. Glial sheath $(g l)$ envelops the glomerular synaplic complex as a whole. $\times 30,000$ 


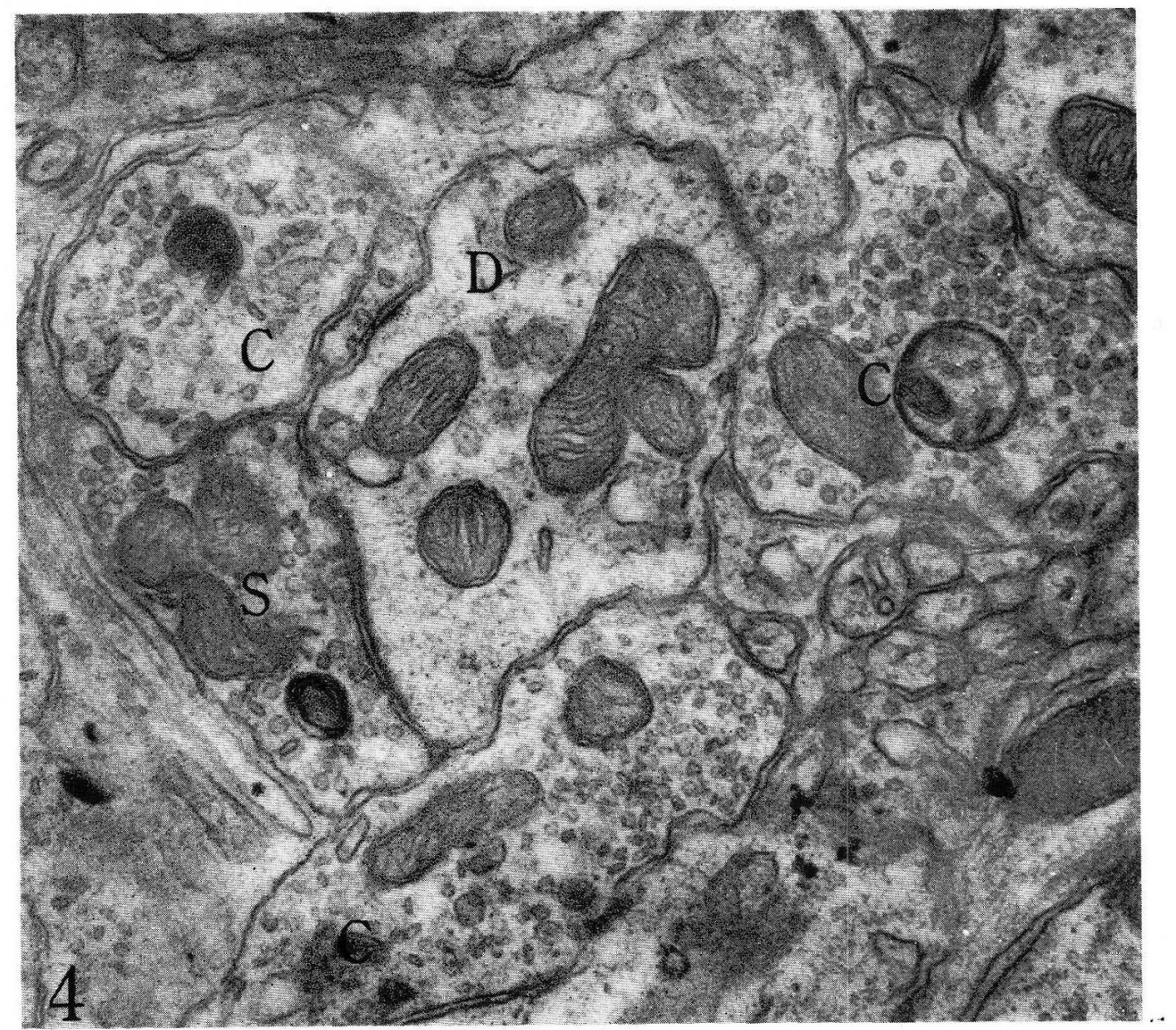

Fig. 4. An example of the synaptic arrangement on the proximal dendritic branches. $D$ proxirral dendritic branch; $C$ c.v.t.: $S$ s. v. t. See the text for further explanations. $\times 38,000$

except for the center of the terminal occupied by a few mitochondria. A few terminals of this type were found containing some large vesicles $(1000 \AA)$ with dense cores in them. In many cases, one terminal of this type makes multiple synaptic contacts at patches of its surface with both dendritic and axonal elements. These morphological characteristics resemble those of the mossy endings found in the hippocampal regions (HAMLYN 1C62) and the cerebellar cortex (GRAY 1961), and therefore we may call the third type also as mossy ending. As to the axoaxonal contacts, the mossy terminals were never seen in postsynaptic situation against the other types of terminals, while the s.v.t. and c.v.t. were often found to be postsynaptic against some other terminals.

Each of these three kinds of terminal appears to be distributed considerably evenly throughout the neuropile of the lateral pulvinar nucleus and the frequency ratio of each type of terminal shows a fairly constant value with only a slight degree of variation among the individuals, when about a thousand of terminals picked up at random from this region are classified and counted. Thus, s.v.t., c.v.t. and mossy terminals occupy respectively $82.5 \%$, $17,0 \%$ and $0,5 \%$ of the whole terminals counted in the region, 


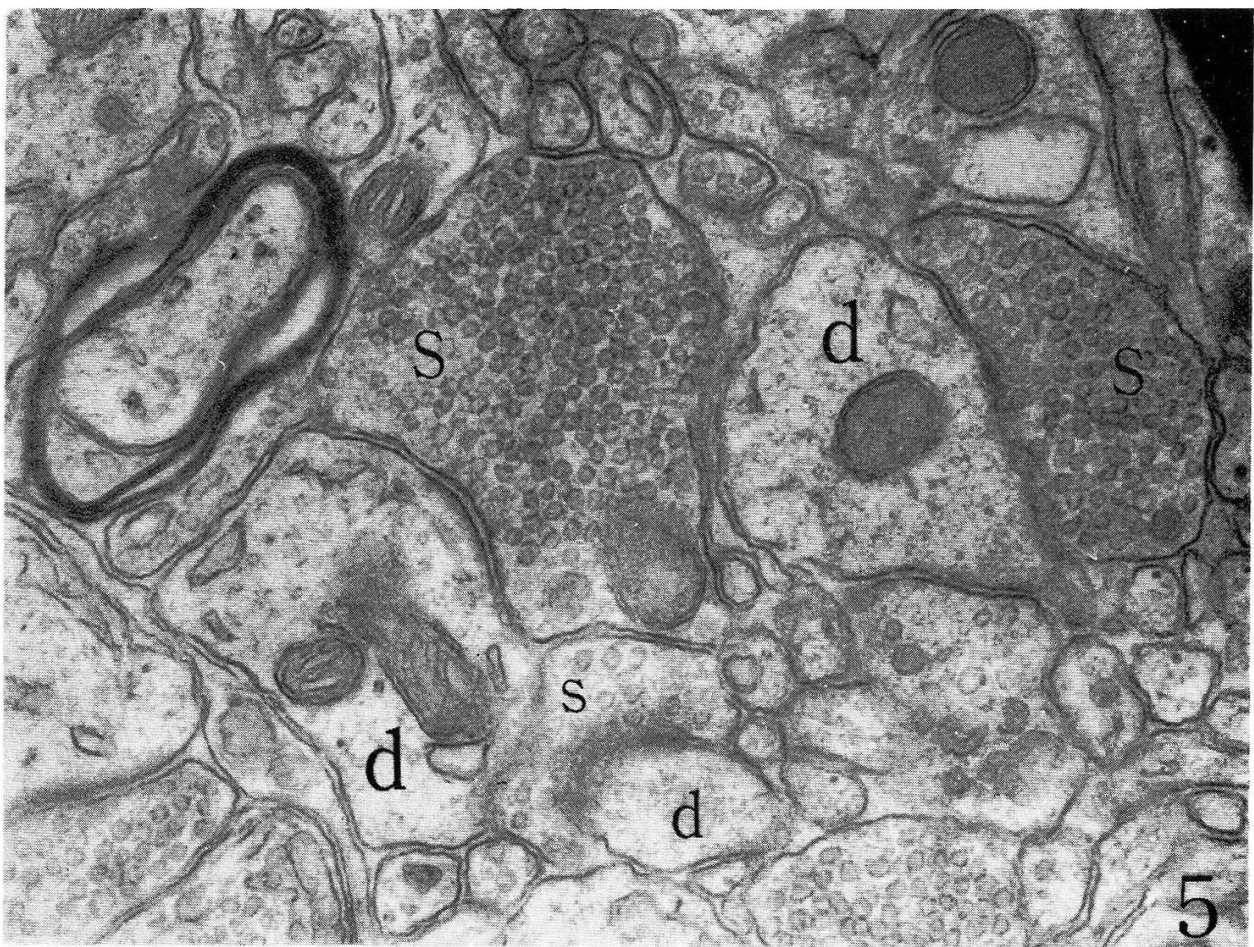

Fig. 5. Synapses on the distal dendritic branches $(d)$. The s. v. t. presail here. $\times 38,000$

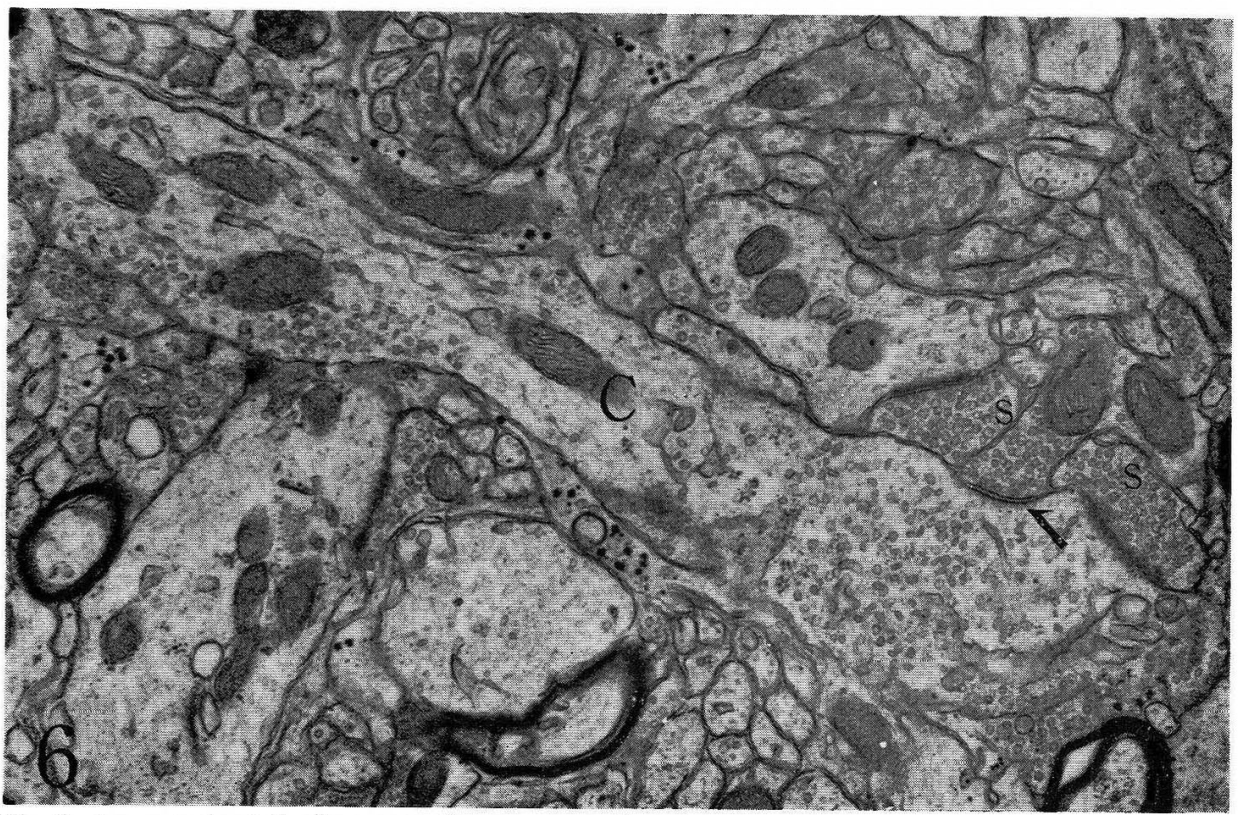

Fig. 6. An example of the "en passant" type c. v. t. Cylindrical vesicles are seen accumulated towards two regions (right and left hands of figure) during the course of the axon. One of the s. v. t. (S) makes synaptic contact (at the arrow) with the c. v. t. $\times 17,000$ 


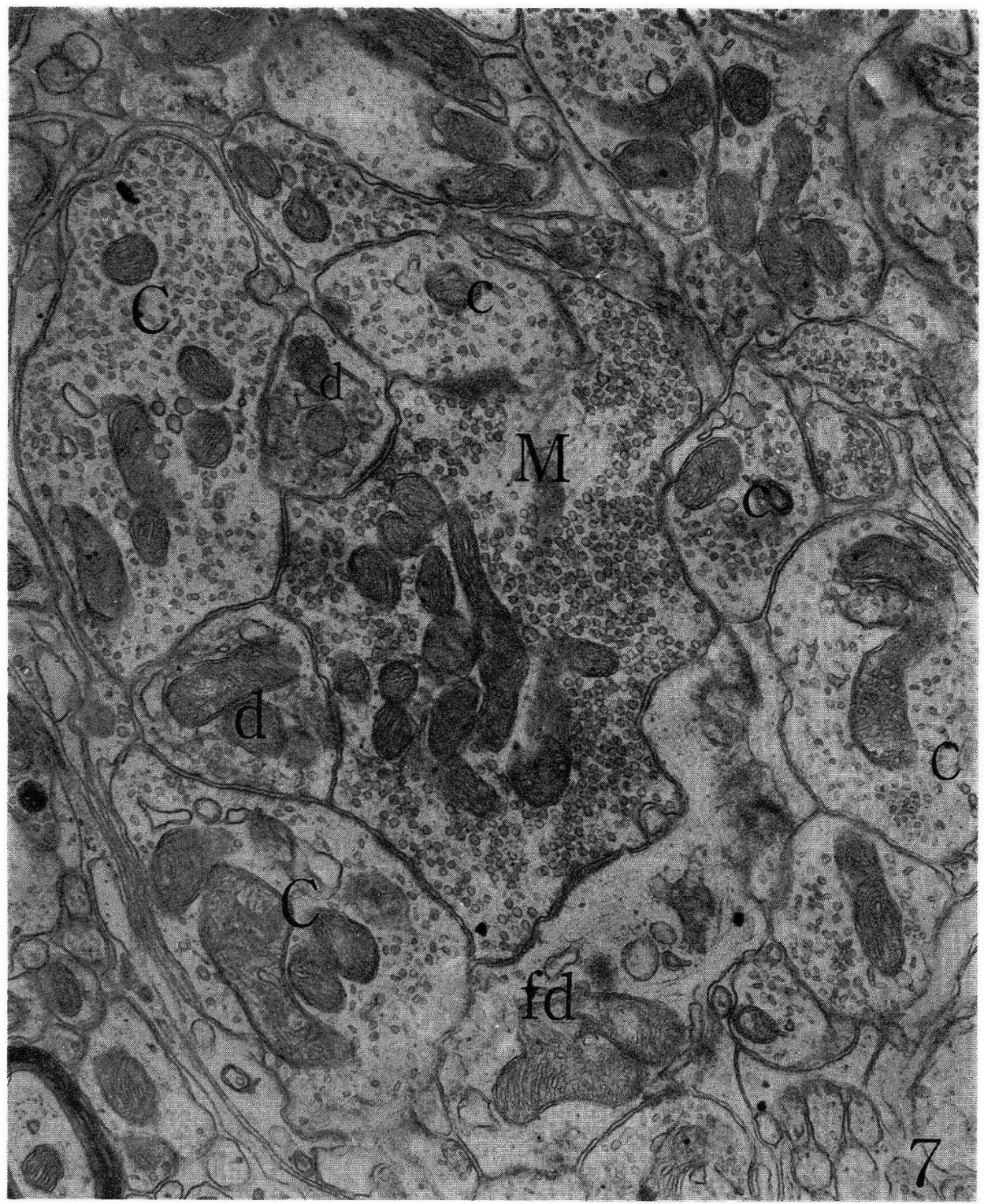

Fig. 7. A large n ossy ending $(M)$ makes multiple synaptic contacts with the c. v. t. (c), distal dendritic branches $(d)$ and a filarrentous dendrite $(f d) . \times 24,000$

\section{Synaptic relationships le'ween the pre-and post-synaptic elements}

1) Synaptic contacts at the short processes derived directly from the dendritic trunk. The synaptic arrangements here seem to correspond apparently to the "large glomerular synapse" of the pulvinar described by MAJorossy et al. (1965). All of the three types of terminals participate in constituting this synaptic complex (Fig. 2, 8). The layout of the various types of presynaptic elements closely packed together around the filamentous centrạl 
dendrite, axo-dendritic contacts between the terminals and the central dendrite, axo-axonal contacts among the terminals and the glial sheath or barrier surrounding the whole synaptic constituents etc. are such as described by the first observers of this peculiar synaptic arrangement. "Large, poor-vesicle axon ending", "small axon ending" and "dark type axon-ending" described by them appear to correspond roughly to the c.v.t., s.v.t. and the mossy ending of the present author respectively. Each of the constituents of the glomerular complex in the present materials, however, presents a certain degree of difference in appearance from that bescribed MAJOROSSY et al. In their materials, furthermore, the clear identification of the different types of the presynaptic elements seems not so easy as in the present materials, likely due to the difference in the fixation method used. As was noted already by the above eited authors, there occur often the axo-axonal synaptic junctions between the terminals around the central dendrite. In such cases, c. v. t. are always postsynaptic against the other types of terminals and, on the contrary, the mossy type of endings is without exception presynaptic to other types of terminals. Some of the s. v. t. in the glomerular synaptic complex seem not to make direct contact with the central dendrite, but rather with c. v. t., which in turn make direct junctions with the dendrite.

2. Synaptic organization on the proximal dendritic branches (Fig. 4, 8). Here, the fundamental arrangement of the presynaptic element against the dendritic branches is similar to the glomerular synarse, but the axon terminals around a dendritic branch are fewer and less closely facked together than in the glomerular synarse and the centrally set profil of the

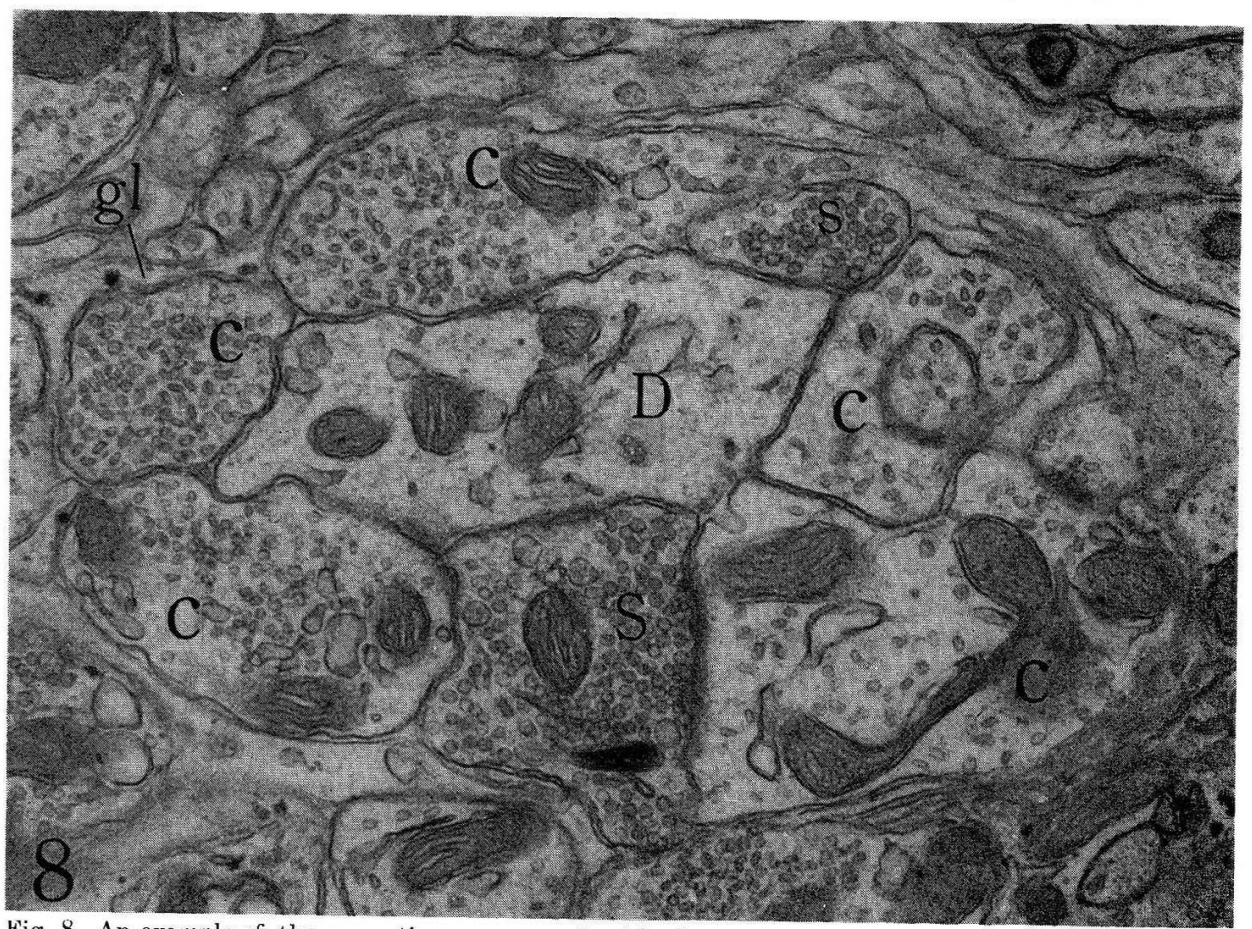

Fig. 8. An example of the synaptic arrangenent with characteristics of both glonerular synapse and synaptic arrangement on the proximal dendritic branch. Though the centrally set dendrite $(D)$ is not filamentous, glial sheath $(g l)$ encircles nearly whole surface of the synaptic constituents as a whole. 
dendrite does not present such a filamentous appearance as was noted in the central dendrite of the glomerular synapse. There also happen the axo-axonal synaptic contacts between the terminals encircling nearly whole surface of the dendritic figures in cross section. Such a nearly complete glial sheath as was noted in the surroundings of the glomerular synaptic arrangement as a whole, is not perceived in this type of axo-dendritic synaptic arrangement. The ratio of the dendritic surface which is apposed to nerve terminals to the whole surface of the dendrite is, while nearly $100 \%$ in the case of the central dendrite of the glomerular synapse, the smaller, the thinner the dendritic branch in concern becomes. The axo axonal contacts between the presynaptic elements, meanwhiles, become the more frequently occurring, the thicker the dendritic branch encircled by these terminals is; and the proportion which the c. v. t. occupy in all the terminals around the proximal dendritic profils is the smaller, the less the diameter of the dendritic branch becomes.

3. Synapses to the distal, or peripheral dendritic branches (less than $1 \mu$ in diamzter). The synaptic contact in this case is rather simple and is formed usually between one or two terminals and a dendritic profil. The presynaptic components are nearly exclusively the s. v. t. Neither the axo axonal contact nor the glial $€$ nvelop is notable here (Fig. 5).

\section{Degentration experiments}

In an attemrt to deciaje the site of the origin of the three types of input to the lateral pulvinar nucles's, we have ablated scme of the ncocortical regicns which have been known to proiect to the pulvinar. Nauta-stains of the materials which survived seven to ten days revealed degenerated fibers in bundles entering from laterally to run transversely through the pulvinar nucleus. Some of these fibers were seen occasionally diverging from the bundle into the cellular areas, but the further division into finer branches, or the scattering of the degenerative figures that suggests the preterminal nature of the degenerated fibers there, were scarcely recognized. Electron microscopically, only a rare occurrence of some abnormal figures of the terminals was noted in some animals which survived three to four days after the cortical ablation. One of these is the structure which is filled with filamentous materials and was suspected to be the degenerated terminal, when referred to the morphological characteristics in the early stage of degeneration previously reported in other regions of the central neryous system (WALBERg 1664, Colonnier 1964 etc.). Except for these few filamentous terminals, no definite findings typical to the degenerative changes of the axon terminals were obtained in this region of the brain from the experimental animals. Some other vague figures suggestive of degenerative process are shown in Figs. 9 and 10. In Fig. 10 from a cat the associarion cortex of which was ablated four days before, some terminals constituting the glomerular synapse have lowered electron density of the matrix and uneven distribution of rather few cylindrical vesicles in it, thus presenting the unusual appearance when compared with neighboring normal c. v. t. Fig. 9 shows the existence of the vacuoles and the peculiar tubular structures in the c. v. t., which was found in the cat whose visual and association cortex was ablated three days before. These figures can give only indistinct indication that the changed terminals may belong to the c. v. t. When about one thousand of terminals in the lateral pulvinar region of the experimental animals were sampled and classified as was done in control materials, however, one can know the definite changes in the constitution of the inputs to this region (Table 1). Although there exist some variations in the percentages according to the location and the extent of the cortical lesion, the common result is that the c, v, t. are reduced in materials whose corticopulvinar projection is partially ablated. Though 
the reduction in the relative percentage of c. v. t. in all terminals in that region does not mean directly that some of the c. v. t. are the axonal endings of the corticopulvinar projection fibers, such conclusion would beccme more valid, when considered with the degenerative figures above described.
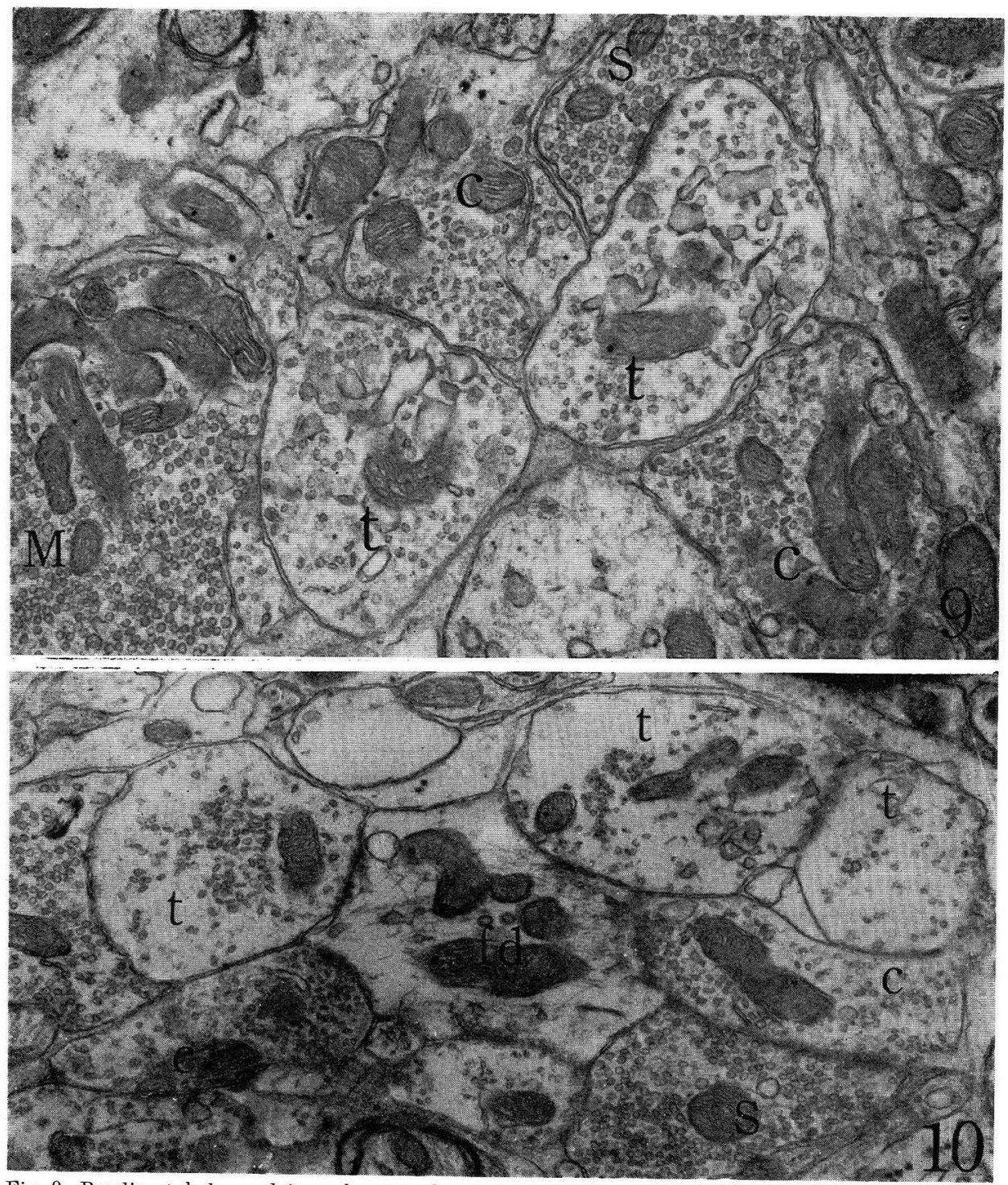

Fig. 9. Peculiar tubules and irregular vacuoles are seen in the terminals $(t)$ which contain cylindrical vesicles. From the cat whose assoziation cortex was ablated previously. Compare these terminals with the neighboring, apparently normal c. v. t. $(C)$. S s. v. t. ; $M$ part of nossy terminal. $\times 23,000$

Fig. 10. Uneven distribution of cylindrical vesicles in three terminals $(t)$ around a filamentous dendrite should be noted. Compare these with neighboring c. v. t. $(C)$. $S$ s. v. t, From the same material as Fig. 9 , 


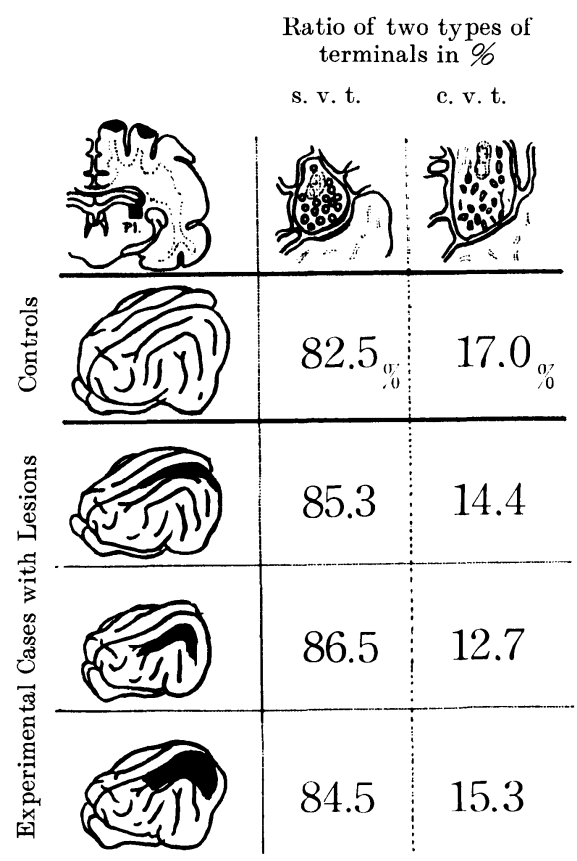

Table 1: Changes in the ratios s. v. t./(s. v. t. + c. v. t. + mossy terminal), and c. v. t. /(s. v. t. +c. v. t. + mossy terminal), after the cortical ablation. Ablated areas are blackened in diagramatic figures of cat's brain.

\section{Discussion}

In analysing the pulvinar synapses, we owe much to the first description by MAJOROSSY et al. (1965) on the fine structure of the synaptic organization of the cat's pulvinar. They stated the risults of their observations in a compl:tely persuading way by combining electron microscopy with skillful Golgi-preparations and scctions with neurofibrillar staining. The matarials studied by the present author were triated differently from those observed by them and this seems to be the main reason of some discrepancies between their results and ours. According to M AJOROSSY et al., the large glom?rular synapses they found are the main and most characteristic type of synaptic contact in this brain region. In the present observation, however, that kind of synaptic arrangement, though really characteristic, constitutes only a small portion of the synaptic inputs to the pulvinar neurous; the main receptive areas of the neurons are, as describad aqove, the proximal and distal dendritic branches, where such glomerular synaptic arrangements as defi ned by them are scarcely found.

It may imply some physiological differentiation of portions of dendrites that the relationships ketwe $n$ various types of the presynaptic elements and the postsynaptically arranged part of the dendrites vary in quality and in quantity according to the thicliness or the dendrites, and hence, to the distances from the neuronal somata. As one of such implications, we can suppose that the proximal, in particular thicker portions of, dendritic kranches would be the sites of more elaborate integrative activity than at the thinner distal branches, since in the former portions there occur more frequent axo-axonal synaptic contacts between different types of the presynaptic terminals surrounding the postsynaptic dendritic branch than in the latter.

In the present study, the ablation experiment induced no definitely convincing figures of the degenerative terminals in the pulvinar region. By calculating the ratio in number which each type of the terminals occupies in th? whole inputs after the ablation of a part of a given type of input (a part of the cortico-pulvinar projection in the present cases), however, the present author could obtain indirsct evidence that the terminal of the cortico pulvinar projection fibers might be of the type of c.v.t. This way of determining the origin of a certain type of the presynaptic elements in a given brain region resembles to a certain degree "the persisting elements" method which was adopted by SzentáGothai (1965). Though the latter method is fruitful when carried out successfully, it has some restrictions in its applicability. In the first place, the nucleus or otherwise circumscribed cellular region of the central nervous system to be studied must have a predominant presynaptic pathway that could be 
completely destroyed or interrupted at a site distant from this nucleus. The brain regions that suffice this condition seem, however, rather limited. The second of the restrictions is that enough time (in many cases a few months) should have elapsed for complete degeneration and resorption of the fragments. But this time seems to be long enough to allow retrograde changes in the nuclear region to be studied if thera exist reciprocal or amphidromic connections between this region an t the destroyed or interrupted site. The resulting retrograde degenerative changes in that nuclear ragion would certainly modify the synaptic arrangements which might be expected when purely presynaptic elements alone were brought into degeneration as was intended first. The method tried in the present investigation can give only indirect and restricted indication about the origin of a part of a certain type of terminals in a given brain region. But, instead, the two restrictions met in applying the method of "persisting elements" are no barriers in this method. Furthermore, since seven to ten days of survival are thought to be enough to reduce, to a perceivable degree, the typa of presynaptic elements to which the axon terminals of the ablated projection fibers belong, the same material can be treated by Nauta-technique which enable to trace the gross projection pathways from the lesioned site. That the result can be quantitatively shown in a diarram of percentages is the additional merit of this method.

From these points, the msthod tried in the present study might have some virtue of utility, especially when combined with other techniques, in analysing the synaptic arrangement in a certain region of the central nervous system at the fins structural level.

\section{Summary}

Synaptic organization of the cat lateral pulvinar nucleus was studied electron microscopically in the materials perfused with buffered formalin solution and post-fixed with $\mathrm{OsO}_{\text {:. }}$ The receptive areas of the pulvinar neuron can be classified into 1) small, direct issues of the dendritic trunk, which make the glomerular synapse (MAJorossy et al. 1965), 2) pro. imal den'ritic branches making complex axo-dendritic synapses and 3) distal fine dendritic branches with rather simple synaptic contacts with nerve termina's. On the other hand, three kinds of axon terminals are identified in the neuropile of the pulvinar: a) most frequently occurring, smaller terminals containing spherical vasicles alone, b) larger terminals with cylindrical vesicles and c) the largest mossy endings of rather rare occurrence. The ratio in num'er of the terminals of each type in about a thousand of terminals sampled at random from this brain region is considerably constant among materials from different control animals. Ablation of the cortical regions which project to the pulvinar induced the changes in this ratio, thus suggesting that the reduced type of terminals might correspond, at least in part, to the endings of the ablated projection fibers. The utility of this phenomenon in determining the type of axon terminals of a given projection system was discussed.

\section{ネコの外側視床枕核のシナプス構成（内容自抄）}

ホルマリンで灌流固定, オスミウム酸で後固定したネコの脳の外側視床枕核を観察し, とくにそのシナプス構成を詳しく検討した.

枕核ネウロンに対する形態学的な意味での入力 (シナプス入力) を示すと考えられる神 経終末に a) 最も多い小型の終末で内に球形のシナプス小胞を含むもの．b）それにくら べやや大型の終末で内に円筒状シナプス小胞（HIRATA 1966）をも含むむの，および c)ま 
れに見られる, かなり大型で, 内に多数の球形シナプス小胞を入れ, いわゆる苔状終末 に似たもの，以上 3 種を区別できる。乙れらの 3 種の終末の数の比は，終末を無作意に約 1, 000 個抽出すると, 外側枕核では一定の值 (a: 82.5\%, b: $17 \%, \mathrm{c}: 0.5 \%$ ) を示し, 個体 差が少い。これらの入力に対する枕核ネウロンの受容野は，入力とのシナプス関係の形態 の違いにより，1）Glomerular synapse（MAJOROSSY et al. 1965）を帅成する小枝で，樹状

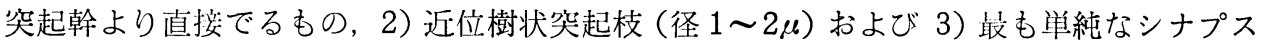
関係をもつ，遠位樹状突起枝（径 $1 \mu$ 以下）に分けることができる.

枕核に投射する皮質野を剔除すると，電子顕微鏡では著明な変性像を認めることはでき なかったが, 上記の入力の構成比が変化し，とくにbの終末が減少することが知られた。

\section{References}

Bodian, D.: Elestron microscopy : two major synaptic types on spinal motoneurons, Science 151: 10931094 (1966).

Colonnier, M.: Experimental degeneration in the cerebral cortex. J. Anat. 98: 47-53 (1964).

Gray, E. G : Axo-so ratic and axo-dendritic synapses of the cerebral cortex : an electron microscope study. J. Anat. 93: 420-433 (1959).

: The granule cells, mossy synapses and Purkinje spine synapses of the cerebellum. Light and electron microscope observations. J. Anat. 95: 345-356 (1961).

Hamlyn, L. H.: The fine structure of the mossy fibre endings in the hippocampus of the rabbit. J. Anat. 96: 112-120 (1962).

Hirata, Y.: Cortical projection field of the cat's pulvinar, with sone observations on the ablation effects of the pulvinar on the animal behavior and the electrical activity of the visual pathways (Abstract, Japanese). Acta anat. nippon. 40: 60-61 (1965).

: Occurrence of cylindrical synaptic vesicles in the central nervous system perfused with buffered formalin solution prior to the $\mathrm{OsO}_{4}$ fixation. Arch. histol. jap. 26 : 269-279 (1966).

Luft, J. H. : Improvements in epoxy resin embedding methods. J. biophys. biochem. Cytol. 9: 409-414 (1961).

Majorossy, K., M. Réthelyi and J. Szentágothai; The large glomerular synapse of the pulvinar. J. Hirnforsch. 7 : 415-432 (1965).

Millonig, G.: Advantages of a phosphate buffer for $\mathrm{OsO}_{4}$ solution in fixation. J. appl. Physic. $32: 1637$ (1961).

- : A modified procedure for lead staining of thin sections. J. biophys. biochem. Cytol. 11: 736 . 739 (1961).

Nauta, W. J. H. and P. A. Gygax: Silver impregnation of degenerating axons in the central nervous system: a modified technic. Stain Technol. 30: 91-93 (1954).

Szentágothai, J.: The use of degeneration methods in the investigation of short neuronal connexions. In: (ed. by) M. Singer and J. P. Shadé: Degenerative patterns in the nervous system (Progress in Brain Research, vol. 13). Elsevier, 1965

Walberg, F.: The early changes in degenerating boutons and the problem of argyrophilia. Light and electron microsbopic observations. J. co.np. Neurol. 122: 113-123 (1964).

Yamamoto, T.; A method of toluidine blue stain for epoxy enbedded tissue for light microscopy. Acta anat. nippon. 48: 124-128 (1963). 